\title{
Freeing Leonardo da Vinci's Fight for the Standard in the Hall of the Five Hundred at Florence's Palazzo Vecchio
}

\author{
Antonio Cassella ${ }^{1}$ \\ ${ }^{1}$ President of Research Autism LLC (FL) and Director of Imerisya (Instituto merideño de investigación de la inteligencia \\ social y del autismo, Mérida, Venezuela). \\ Correspondence: Antonio Cassella, 1270 N. Wickham Rd. 16-613, Melbourne, FL, 32935, USA.
}

Received: August 17,2017

Accepted: September 1,2017 Available online: September 18,2017

doi:10.11114/ijsss.v5i10.2657

URL: https://doi.org/10.11114/ijsss.v5i10.2657

\begin{abstract}
In June 2017, the author wrote an article in the International Journal of Social Science Studies in which he hypothesized that the Hall of the Five Hundred at Florence's Palazzo Vecchio has been protecting the central piece of Leonardo da Vinci's mural Battle of Anghiari: The Fight for the Standard (La Lotta per lo Stendardo) under Giorgio Vasari's painting Battle of Marciano for 512 years now. On the evening of August 10, 2017, the author read a veiled message left by Vasari: The vertical line that passes through the center of the Battle of Marciano also passes through the center of the Fight for the Standard. On the evening of August 15, the author read a second secret message left by Vasari: The bottom of Leonardo's Battle of Anghiari aligns with the floor of the Hall of the Five Hundred. Beyond previous hypotheses, the author envisions here that, after drilling a 1/2-inch hole at 0.915 meters from the floor, on the vertical line that leaves the virtual larynx of the screaming supine soldier in the Battle of Marciano, a laparoscope will point at the virtual larynx of the yelling prostrate soldier in the Fight for the Standard. Our wild assault against the wild and against humanistic intelligence is unsustainable. From a humanistic standpoint, the quantum-computing search to see again the classical-computing conflict attached to the Fight for the Standard will lead to a global Renaissance: The union of ancient knowledge about social values with modern scientific and technological skills will dispel global warming and fundamentalist-driven terrorism, while freeing our descendants to explore the cosmos in the next 7000 years.
\end{abstract}

Keywords: classical computing, quantum computing, social values, Humanism, Renaissance

\section{Introduction}

Our human ancestors survived harsh conditions during 200000 years by valuing spontaneously the reciprocal empowerment of classical computing and quantum computing in nature and in the mind. In simpler words, Neanderthal and African humans treasured both our classical ability to rally around a common frame of beliefs in confronting others and our quantum talent for suspending and even changing shared beliefs when context shows that they will be counterproductive. The necessary and yet insufficient classical facet of rigid confrontation revisits modern reality when we seek a resolute victory over a competitor.

In 1504, Leonardo da Vinci agreed with Florence's Gonfaloniere for Life Piero Soderini to paint in the Hall of the Five Hundred of the Florentine Palazzo della Signoria a mural about the resolute victory that the Republic of Florence had achieved at Anghiari, in a battle with Pisa and their fierce Milanese allies. The center piece of Leonardo's Battle of Anghiari is the Fight for the Standard - an unresolved fight for a standard among four horsemen. The classical conflict addressed by Leonardo's art is a memento of the quantum opportunity to avoid taking sides in a rigid confrontation before recognizing and solving an underlying problem — just as flexible jurors do before they envision a verdict that in the end will favor either the rigidity of the prosecutor or the rigidity of the defense lawyer.

Finding the Fight for the Standard of Leonardo's Battle of Anghiari will help us confirm the principles that rule the creative alliance of quantum and classical computing in nature and in minds that value reversible thought before irreversible action. I also believe that uncovering the Fight for the Standard will convince some tyrants to desist from conquering the world and enslaving others in order to enhance their standard of life, their narcissism, their corruption, and the corruption of their cronies and proxies.

In a June article on the International Journal of Social Science Studies (Cassella, 2017c), I elaborated on the hope of 
Senator Edward Kennedy that democratic societies will succeed in transforming into progress the dangers of terrorism and global warming. If we ever try to overcome terrorism and global warming through the ill-conceived law of a unique, narcissistic winner, our great grandchildren will curse us after suffering an untold pain and before submitting to a premature death. At this juncture, it therefore becomes imperative that we seek out Leonardo's Fight for the Standard in the Hall of the Five Hundred at Florence's Palazzo Vecchio.

The challenge is that no one knows where, when, and what piece of the Battle of Anghiari survived the disaster that beset Leonardo in 1505 when the mix of pigments and linseed oil he had applied somewhere in the Hall of the Five Hundred melted down during his attempt to dry his mural forever. Some documents (Anonimo Gaddiano, 1893) assert that the heat applied by Leonardo had been insufficient, while other documents (Giovio, in Tiraboschi, 1823) assert that the preparation of the wall was flawed. Leonardo himself told Soderini that a faulty linseed oil caused the problem (Kemp, 2006). Giorgio Vasari (1568) wrote that Leonardo tried to return to the Florentine authorities part of the money he had received from them, and that Soderini refused to take any money back, aligning progress with the contractual terms agreed by the parties. In May 1506, Leonardo left Florence, never to finish what he had begun.

By mid-century, after the Medici family returned to that city, Duke Cosimo I moved his office to the Palazzo della Signoria and asked Giorgio Vasari to renew that palace. When he moved out, the Palazzo della Signoria became Palazzo Vecchio, and the fierce horses and horsemen that had animated the Fight for the Standard vanished from sight. If we believe the guide to Florentine works of art written by Albertini in 1510, Leonardo's horses had been in the Hall of the Five Hundred before Cosimo I and Giorgio Vasari renewed the Palazzo della Signoria. However, some experts (Hatfield, 2007) believe that Leonardo's horses could be in a different hall; for example, the incongruous Loggia dei Gonfalonieri di Compagnia e dei Dodici Buonuomini.

In December 2011, Maurizio Seracini and a team organized by the National Geographic Magazine drilled a few holes in Vasari's painting Battle of Marciano, located at the southern end of the east wall of the Hall of the Five Hundred. In early 2012, Seracini announced that his team had found remains of pigments that Leonardo used in painting the Gioconda (Mona Lisa). In my view, da Vinci knew that clear confrontation is simultaneously necessary and insufficient. That is the reason why he added at night the enigmatic smile of Mona Lisa to the clear hatred he displayed during the day in the four horsemen that animated his Fight for the Standard and the whole Battle of Anghiari at the Palazzo della Signoria. In the end, the search initiated by Seracini was aborted due to the ferocious dissent among inimical parties, in line with the relentless animosity that energizes the Fight for the Standard.

The fact that the National Geographic Magazine did not find any trace of the Volterra plaster, which Leonardo had bought to condition the wall that received the centerpiece of the Battle of Anghiari, reinforces the hypothesis of some (e.g., Hatfield, 2007) that Leonardo never painted his mural in the Hall of the Five Hundred, and that the words "CERCA TROVA" ("SEEK AND YE SHALL FIND") written on the upper part of the Battle of Marciano are meaningless. In an article I wrote a year ago in the Journal of Arts and Humanities (Cassella, 2016), I followed Seracini in my belief that the words "CERCA TROVA" represented an essential lead left by Giorgio Vasari. I believed then, as I believe now, that Seracini was right when he proposed that the remains of the Battle of Anghiari-particularly, the Fight for the Standard-lie in the Hall of the Five Hundred. Operating under the belief that the words "CERCA TROVA" were true, I even hypothesized a year ago that the Fight for the Standard, copied by Peter Paul Rubens in 1603 (presumably from Leonardo's cartoon), lied in an interspace behind the interspace searched by the National Geographic Magazine.

On March 10, 2017, Martin Kemp ${ }^{1}$ pointed out to me that the words "CERCA TROVA" was a red herring. This observation changed my belief in the veracity of those words to utter disbelief in their worth. A changed research method led me to express in my June 2017 article a readjusted null hypothesis that the Fight for the Standard lies under and not behind Vasari's Battle of Marciano. By the end of July, I considered that Giorgio Vasari was too good of a painter and architect not to leave behind a better clue than the vague words "CERCA TROVA." In reexamining Vasari's paintings and writings, I found on August 10, 2017 that the vertical line that passes through the exact center of Vasari's Battle of Marciano also passes through the exact center of Leonardo's Fight for the Standard.

After finding the horizontal placement of the Fight for the Standard, I set the height of the center of Leonardo's central piece of the Battle of Anghiari at 6.55 meters below the center of the Battle of Marciano, with an error of \pm 48.5 centimeters. On the evening of August 15, 2017, however, I checked my hypothesis about the vertical placement of Leonardo's Fight for the Standard by standing virtually in front of the door located under the Battle of Marciano. Knowledge that the Fight for the Standard has a height of 4.53 meters, coupled to my virtual measurement (5.5 meters) of the distance between the bottom of the Battle of Marciano and the floor of the Hall of the Five Hundred, demolished the uncertainty of \pm 48.5 centimeters. Indeed, the involved ambiguity implies the destruction of $50 \%$ of the lower frame

\footnotetext{
${ }^{1}$ Martin Kemp is Professor Emeritus of history of art at the University of Oxford.
} 
of Vasari's upstanding painting. I believe that Vasari's architectural aesthetic would have never followed such an inelegant undertaking. Consequently, I concluded a few days ago that the unusual height and bulge of the frame around Vasari's six paintings in the Hall of the Five Hundred represents a second key, which places the bottom of Leonardo's mural at the same level of the floor of that hall.

The center of the Fight for the Standard, then, lies at 7.035 meters below the center of the Battle of Marciano.

This article aims to describe the serendipitous process that led me to a vision past hypothetical constructs. Here, I go beyond the deceptive coherence of the hypothesis I expressed in the article published in August of 2016. I also disabled the doubt of the readjusted hypotheses I gave in my June article (Cassella, 2017c). Actually, a spontaneous vision has replaced: a) the fear that surrounds people without knowledge, b) the clarity that surrounds arrogant characters, and c) self-doubt experienced by those who cannot interpret their own dreams. According to the teachings that the anthropologist Carlos Castaneda $(1968,1974)$ received from his enigmatic mentor Don Juan, leaving behind fear, clarity, and the unilateral use of our dreaming power will transform any hunter into a warrior first, and then into a man- or a woman-of-knowledge. I am far from that eventuality.

In fact, it cannot be ascertained if the readers of this article, the workers of the Opificio delle Pietre Dure (OPD) that governs the decision to make changes in the Hall of the Five Hundred, and the Florentines that will follow the defiant ways of the defenders of the standard of the Battle of Anghiari in cutting forever any intruding hand, will ever believe the distant reasoning and measurements I present here. It is also impossible to know if they would all accept my proposition of freeing the yell of the supine dying soldier in the Fight of the Standard by drilling a $1 / 2$-inch (DIAMETER) hole in the empty wall under Vasari's Battle of Marciano, at 0.915 meters (about three feet) from the floor, on the vertical line that comes down from the tip of the dagger that enters the open mouth of a dying supine soldier in that painting by Vasari.

\section{Method}

The facts exposed in the background section, coupled with the reasoning expressed in the following discussion section, lead to a proposal in my concluding remarks that may change the trajectory of the human disposition of moving from worse to worst into the humanistic elegance of moving instead from good, to better, and then best.

\section{Background}

\subsection{The Ancient Crystals Kept in the Ark of the Covenant, the Two Staffs of God, and the Return of Quetzalcoatl}

I enhance first the view of the three ways of attention-intention that comprise the backbone of the logos heuristic $(\Lambda)$ (Cassella, 1997, 2000, 2002a, 2002b, 2008, 2011, 2013, 2016, 2017a, 2017b, 2017d, 2017e, 2017f), which I sketched in my June article in the International Journal of Social Science Studies (Cassella, 2017c):

1. The classical first attention spared in high-functioning autism corresponds to reliable memory and shared respect in the crystal Thummim that the kings of Israel kept in the Ark of the Covenant; the staff Hovalim envisioned by the prophet Zechariah in the $5^{\text {th }}$ century before the common era; and the Tonal described by Don Juan to Carlos Castaneda (1974). The Tonal echoes the enmity between the autistic knowledge prized on land by the "coatl" ("serpent" in Nahuatl) that inhabits the pyramid of the Sun at the abandoned Mexican city of Teotihuacan and the unilateral craziness of the "quetzal" ("bird" in Nahuatl) in the sky (Cassella, 2017b).

2. The second attention, damaged in autism and schizophrenia, corresponds to the creative talent enclosed in the crystal Urim, also kept in the Ark of the Covenant, the staff No'am dreamed by Zechariah, the Nagual feared by Carlos Castaneda (1974), and the going voyage of the Mesoamerican demi-god "Quetzalcoatl" toward madness through quantum coherence, the pyramid of the moon at Teotihuacan, and the Morning Star.

3. Within quantum decoherence, the third attention represents the union of artistic talent and shared respect in favoring the alliance of the staff Hovalim with the staff No'am, of the crystal Thummim with the crystal Urim, the Eagle that unites the Tonal with the Nagual (Castaneda, 1981), and the return of Quetzalcoatl to his pyramid at Teotihuacan with the Evening Star.

Joseph Smith, for example, used the crystals Thummim and Urim that he received from the angel Moroni- to translate the ancient Book of Mormon into English. His basic message (D\&A 130:6/11) - that the place in which God resides is a great Urim and Thummim - is hidden in all Sacred Texts, masterpieces of the arts, natural systems, and in the uncontaminated minds of children.

The crystal Thummim, the staff Hovalim, the Tonal and the autistic coatl follow two down-to-earth principles, namely that nobody can: a) be in two places simultaneously (Locality); and b) share the same space at the same time with someone or something else (Impenetrability). The crystal Urim, the staff No'am, the Nagual, and the going Quetzalcoatl follow two creepy principles, namely that the everybody can: a) be in two places simultaneously (Ubiquity); and b) 
share the same space with someone or something else at the same time (Coincidence).

The nonautistic devils who "lie" in separate contexts simultaneously evoke the infinite speed in Ubiquity. Similarly, transcendental zero in Coincidence pervades the ability of our implicit self to return to a better reality by sharing the same space with our worst enemies. The Quetzalcoatl that goes with the Morning Star will make a pact with the devil before making a pact with his enemies. By contrast, the Quetzalcoatl that returns with the Evening Star to her pyramid at Teotihuacan will convince her worst enemies to help her save humans and nonhuman animals from dying in slavery. In saving the biota and humane civilization, the returning Quetzalcoatl will stop at nothing but a green traffic light.

\subsection{Stopping at a Green Traffic Light}

Imagine that we are approaching an intersection ruled by a red traffic light. Our autistic facet would help our foot press the brake-pedal that would stop our car. The first attention that drives the autistic facet of our Tonal-Thummim-Hovalim believes that there is no way that we can share the same space at the same time (the principle of Impenetrability) with the competing drivers freed by a green light, or that we can escape a collision by moving instantaneously from a dangerous intersection to our home (the principle of Locality). Similarly, if we approach an intersection ruled by a green light, our autistic coatl-facet will continue pressing the accelerator, under the belief that the first attention of our competitors will obey its own principles.

Beyond the autistic coatl cherished by our explicit self, the law says that the right to continue crossing an intersection under the protection of a green light is given by the rival driver that stops in front of a red light. When the principles of Ubiquity and Coincidence in our Nagual-Urim-No'am inform our implicit self that an opposing driver will disregard the red light, our explicit self may ally with our implicit self in reducing the speed of our car or in stopping it altogether. That social action could save a life.

The force that invites our foot to press the brake in front of a green light comes from the Eagle of the third attention of the returning Quetzalcoatl, and does not come from the second attention in the insolent Quetzal-coatl that accelerates during a yellow light. In the center of a virtual intersection, in which the implicit self that traveled in our car shares the same space at the same time with the implicit self that traveled simultaneously in a competing car, transcendental infinite becomes transcendental zero (and the principle of Ubiquity embraces the principle of Coincidence) in the awakened Quetzalcoatl that stops before having an accident. Empowered judges punish intoxicated drivers that lose: a) the autistic respect of their Thummim-Tonal-Hovalim for stopping at a red light and for going at a green light, b) the artistic talent of their Urim-Nagual-No'am for dealing with a yellow light, and c) the social insight of their third attention —or the place in which God resides — for stopping at a green light when a rival driver does not follow the order imposed by a red light.

\subsection{The Double Green Light of Leonardo's Battle of Anghiari}

Leonardo da Vinci was inspired by the alliance of the crystals Thummim and Urim when he designed the cartoon of his Battle of Anghiari, which included the cartoon of the Fight for the Standard. People filled with hatred, however, would transform Leonardo's $16^{\text {th }}$ century Fight for the Standard into a crazy intersection in which rival drivers are excited by a double green light. It is not easy to see that the Fight for the Standard painted by Leonardo contains more than two sides that try unwisely to annihilate each other.

Although the Fight for the Standard at the center of the Battle of Anghiari shows no winner, the Gonfaloniere for Life Piero Soderini and all Florentines appreciated Leonardo's divine knowledge of the quirks of soldiers and horses, which he had learned ten years before as a military engineer to Ludovico il Moro, the Duke of Milan. Any artist knows that winning puts an end to the passion behind an unresolved dispute. In the ongoing battle to seize a standard, Leonardo captured the essentiality and insufficiency of a serious confrontation, which collects the blood of the people that refuse to follow the beliefs of their enemies, while trying to impose as law their own beliefs.

\subsection{A First Look at the Words "CERCA TROVA" on the Battle of Marciano}

In the late part of 2011, a research team directed by Maurizio Seracini failed to find da Vinci's Battle of Anghiari in the newer Hall of the Five Hundred behind the painting Battle of Marciano by Giorgio Vasari. However, the researchers found remains of unique red and black pigments that Leonardo used to paint the Gioconda by night and the Battle of Anghiari by day. Maurizio Seracini also found that the wall that sustains the washed out remains of Leonardo's work had been conditioned with a calcium-carbonate plaster base.

Seracini's exploration was motivated by the mysterious words "CERCA TROVA" painted on a banner of the losing side in the upper part of the Battle of Marciano. The existence of several copies of the Fight for the Standard, Seracini's findings, and his insistence on the fact that no artist but Vasari touched the walls of the Hall of the Five Hundred after Leonardo did, suggest that the Fight for the Standard - the least damaged part of Leonardo's Battle of Anghiari-remains concealed in that hall. 


\subsection{Proof that the Fight for the Standard Lies in the Hall of the Five Hundred}

A few historical documents support Seracini's view that the Fight for the Standard lies in the Hall of the Five Hundred:

1. An unknown biographer in the Anonimo Gaddiano (XVI secolo, fol. 121. Cod. Magliab. XVII, Biblioteca Centrale di Firenze) wrote: “. . . et di Plinio cavò quello stuccho con il quale coloriva, ma non l'intese bene... poj la volse mettere in opera nella Sala, dove giù basso il fuoco agiunse et seccholla, ma lassù alto, per la distantia grande non vi aggiunse il calore et colò". (“. . . and from Pliny he took the encaust with which he colored, but he did not understand it well . . . after that he wanted to implement it in the Hall, where in the lower part the fire dried it: but in the highest part, due to the great distance, there was no addition of heat and it ran down").

Although the interpretation of the Anonimo Gaddiano may be faulty, it nonetheless stresses that Leonardo had painted his Battle of Anghiari on a wall of the Hall of the Five Hundred.

2. On March 14, 1505, the artist moved to the Hall of the Five Hundred the cartoon of the Battle of Anghiari, which he had built in the Hall of the Pope, at the Church of Santa Maria Novella.

3. On June 6, 1505, torrential rain disrupted his work while he was painting at the convened location.

4. Francesco Albertini wrote in 1510 that: "Nella sala grande del consiglio maggiore, lunga braccia 104 larga $40 \grave{e}$... li cavalli di Leonardo Vinci et li disegni di Michelagnolo." ("In the large hall of the great council, 104 braces long and 40 braces wide are the horses of Leonardo Vinci and the drawings of Michelangelo."

5. The bishop Paolo Giovio wrote around 1527 (Tiraboschi, 1823): "Manet etiam in Comitio Curiae Florentinae pugna atque victoria de Pisanis praeclare admodum, sed infeliciter inchoate vitio tectorii colores juglandino oleo intritos singulari contumacia respuentis. Cujus inexpectatae justissimus dolor interrupto operi gratiae plurimum addidisse videtur." ("Moreover, in the Hall of the Florentine Senate one can clearly admire a battle and victory over the Pisans, although quite unhappily a faulty plaster was singularly repulsive to colors impregnated with nut oil. The pain caused by such an unexpected interruption adds to the visual grace of that work.")

6. In the $16^{\text {th }}$ century, Giovanni Paolo Lomazzo (1785, p. 43) wrote: "Ora Leonardo fu quel che lasciato l'uso della tempera passò all'olio, il quale usava assottigliar con i lambicchi, onde è causato che quasi tutte le opera sue, si sono staccate dai muri, siccome tra l'altro si vede nel consiglio di Fiorenza la mirabil Battaglia ." ("Now Leonardo was the one who, setting aside the use of tempera, passed to oil, which he made lighter by using stills, the reason why almost all his works have left the walls, as one can see among many other works the famous battle in the Council of Florence.")

In May of 1506, Leonardo left Florence. Although he came back to that city in order to claim his share of his father's estate, he left unfinished his work there. About half a century later, when the Medici family reclaimed back the Hall of the Five Hundred, the Duke Cosimo I asked the architect and painter Giorgio Vasari to elevate the ceiling of that hall by 12 "braccia" (seven meters). At that point, Leonardo's masterpiece vanished under Vasari's ironical testimony and the lack of historical documentation about its exact location.

\section{Discussion}

\subsection{The Horseman with a Large Red Hat}

In his writings (1568), Giorgio Vasari described the Fight for the Standard with passion, without stating if he observed the details he gives on the cartoon prepared by Leonardo or on a wall of the Hall of the Five Hundred. For no known reason, he emphasized the ongoing confrontation between two soldiers (lower right side of Figure 1) —one kneeled upon the other, under the legs of Leonardo's horses. Notice that Vasari's description of that struggle does not match the incorrect Tavola Doria, but rather Leonardo's correct cartoon.

At this point, I review an observation placed by Godart (2012):

If Giorgio Vasari had gathered his passionate description from the original uncolored cartoon, whence his knowledge that the central horseman-who lifts a curved sword with his right hand, while his left hand grabs the standard at the center of the fight-wears a big "red" hat? ("Berrettone rosso"; left upper side of Figure 1). 


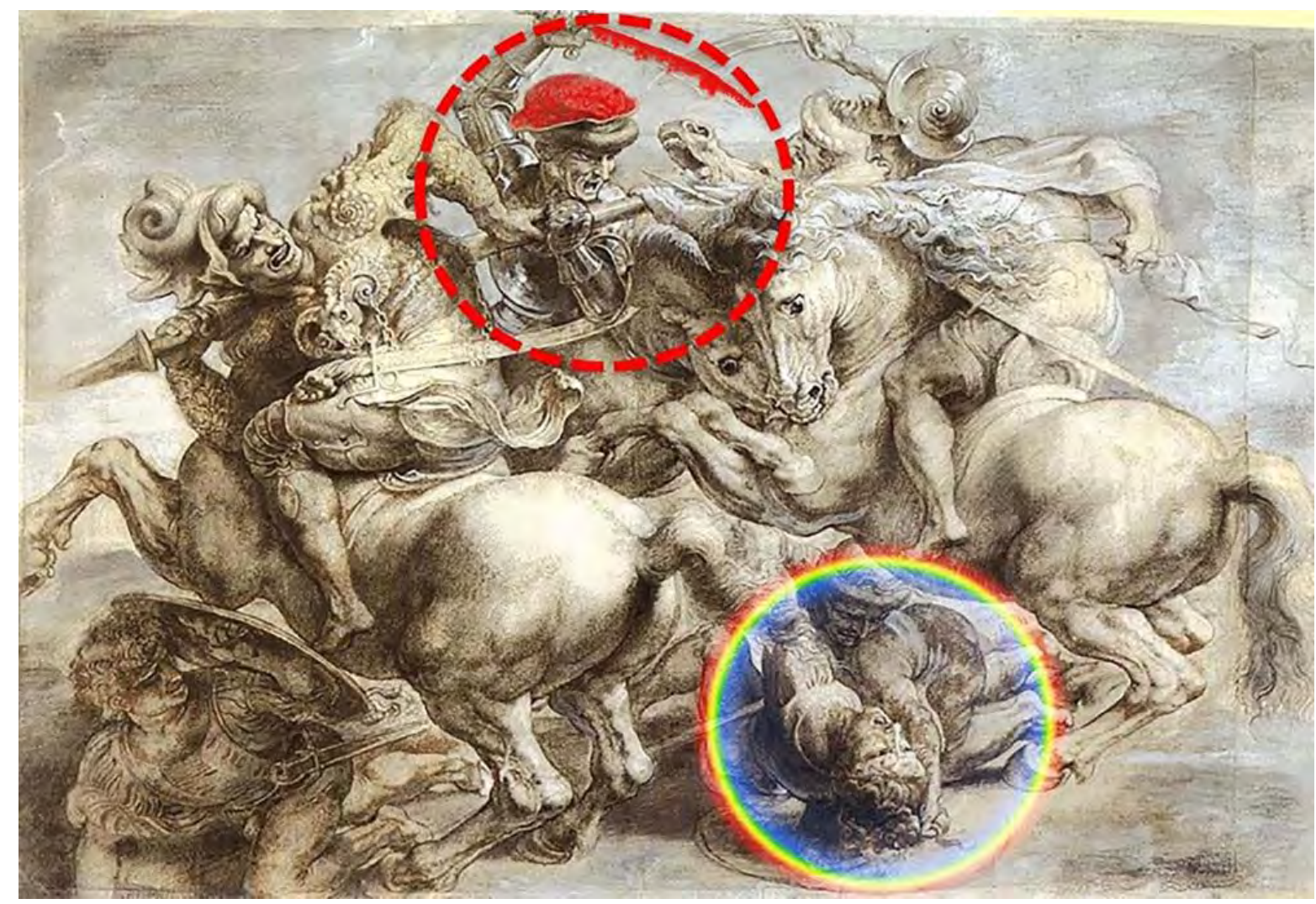

Figure 1. The horseman with the "big red hat",

\subsection{The Confrontation between Calcite Plaster and Alabaster Plaster}

The documentary-film about the findings of Seracini's team stated in 2012 that the wall behind Vasari's Battle of Marciano had been plastered with a white stuccho made of calcium carbonate. As it goes, I missed that key detail until mid-July 2017. Coincidentally, Martin Kemp wrote to me on July 30, 2017, that the absence of Volterra gypsum (a hydrous sulfate of calcium) in Seracini's samples was troubling.

From Kemp's research (2006), I learned that, among many different materials, Leonardo had purchased 343 pounds of sulphate of lime from Volterra, 11 pounds and 4 ounces of linseed oil, and 260 pounds of wall plaster (the white calcium carbonate detected by Seracini). Gaetano Milanesi (in Godart, 2012) wrote that Leonardo bought 663 pounds of plaster, 223 pounds of linseed oil, and only 11 ounces of nut oil. I concluded that Leonardo had used a calcite or calcium-carbonate plaster in the upper portion of the Battle of Anghiari and an alabaster or calcium-sulfate plaster in the lower part of his mural. Therefore, on August 3, I wrote back to Martin Kemp that the Volterra plaster would be found in the place in which it was used: under Vasari's Battle of Marciano.

It must be noted that Leonardo was an innovative and simultaneously careful artist, and that lack of heat, per se, would not ruin his mural. I realized, five years after the release of the documentary-film of Seracini's exploration, that Leonardo failed in drying the upper portion of the Battle of Anghiari because he applied a mix of pigments and linseed oil onto a calcite-derived plaster; also, that he succeeded in drying the lower portion of his mural - the Fight for the Standard - because he conditioned the underlying wall with an alabaster-derived plaster.

Research conducted by Rehhof, Akkermans, Leonardsen, and Thuesen (1990) indicates that plasters made from calcite have protected Indian monuments for millennia. At this point, I infer from Bishop Giovio's comment about a faulty plaster in the Battle of Anghiari (Tiraboschi, 1823) that Leonardo's mix of pigments and linseed oil never penetrated the 260 pounds of calcium carbonate plaster that he had used in conditioning the upper part of the wall that hosted his mural.

\footnotetext{
${ }^{2}$ The berrettone of Niccoló Piccinino is uncolored in the cartoon drawn by Leonardo. I darkened the hat that collected the blood that I placed on the blade of Piccinino's storta, and placed a circular rainbow around the supine soldier. All the paintings shown in the article here are in the public domain. All translations from Latin and from ancient Italian are mine.
} 
I suggest here that Leonardo knew that the use of calcite, instead of alabaster, had precipitated the disgrace that beset him after he applied too much heat - and not too little heat - in the vicinity of a plaster (the calcium carbonate attached to calcite) less vulnerable to heat, humidity, and mold, but with little capacity for absorbing the mix of oily pigments that Leonardo intended to dry forever. At that point, he could not correct his mistaken method to condition the wall that would support the upper portion of the Battaglia di Anghiari.

All in all, the Fight for the Standard survived the catastrophic mistake made by Leonardo. Searching for the central piece of the Battle of Anghiari, or the Fight for the Standard, in the Hall of the Five Hundred is quite reasonable. The search, however, cannot lean on the veracity of the words "CERCA TROVA."

\subsection{Leaving a Red Herring Behind}

As I stated before, a year ago I was led to believe, with the incorrect information I had at the time of writing (Cassella, 2016), that: a) Vasari himself had written the words "CERCA TROVA"; b) Cosimo I (the Medici who ruled Florence when Giorgio Vasari modified the Hall) did not like the tribute to a battle won by the Republic of Florence; c) the painter lodged in Vasari discreetly made a realistic copy of the damaged Battle of Anghiari with the goal of destroying it in front of Cosimo I; and that d) the architect hidden in Vasari preserved Leonardo's mural under that nose of Cosimo I-perhaps in an interspace behind the interspace explored by Maurizio Seracini and the National Geographic Magazine.

After receiving Martin Kemp's implicit advice on March 10, 2017 that I should abandon the red herring provided by the words "CERCA TROVA," I began positing new hypotheses about the location of the central piece of Leonardo's Battle of Anghiari. In my June article in the International Journal of Social Science Studies, my null hypothesis placed the Fight for the Standard under Vasari's Battle of Marciano, whereas my alternate hypothesis placed it under the painting Conquest of Porto Ercole.

My newer hypotheses rested on a different chain of reasoning: a) Vasari would have never dared to deceive Cosimo I, who had learned the art of deception from his father, the Condottiere Giovanni dalle Bande Nere, and from his grandmother, Caterina Sforza, a Condottiera that had survived the prison and associated torture imposed by the devilish Cesare Borgia; $b$ ) if the tyrannical Cosimo I had agreed to pay for the preservation of the badly damaged upper portion of Leonardo's Battle of Anghiari-as Seracini's search in December 2011 suggests - he would also have agreed to pay for the preservation of the undamaged lower part; and c) in the documentary-film on Seracini's exploration, the movement of a few particles of dust, which came up from an unexplored hole in the lower part of the interspace he had searched, suggested to me that there is an empty space between two walls "under" Vasari's Battle of Marciano.

In the article published in June by the International Journal of Social Science Studies, my null hypothesis was strengthened by a few coincidences that came up after I placed a scaled version of Leonardo's Fight for the Standard under a similarly scaled version of the Battle of Marciano. Nevertheless, I always aimed at going beyond hypothetical locations. In late July and early August, the exchange of information I had with Martin Kemp led me to a challenging possibility: Giorgio Vasari, a foremost admirer of the art of Leonardo da Vinci, concealed in one of his paintings in the Hall of the Five Hundred or in his writings a true message about the exact location of Leonardo's Fight for the Standard.

\subsection{Dealing with the Horror of a Bloody Confrontation in Vasari's Paintings}

Because Leonardo's Battle of Anghiari is about the supreme need and the supreme horror of a confrontation between clashing factions, a situation revered by the first attention, I reasoned in early August that Vasari would voluntarily leave a reliable link between confrontation and horror in anyone of the paintings he left in the Hall of the Five Hundred and confrontation and horror in Leonardo's Battle of Anghiari.

On August 9, I studied the six paintings by Giorgio Vasari exposed in the Hall of the Five Hundred at Florence's Palazzo Vecchio and in the digital collection kept at Wikimedia Commons. I noticed that only the painting Battle of Marciano contained a terrifying scene in progress about the violent confrontation between opposite factions (Figure 2).

After meeting true horror in the mutual killing of the two soldiers inside a circular rainbow in Figure 2, I searched for the general confrontation that welcomed the arrival of death into the spacetime illuminated by the first attention. I soon discovered that there is indeed a snake-like line of confrontation in Vasari's Battle of Marciano. That line ends in the open mouth of the madly screaming Siena soldier, whose impending death by the hand of a stronger soldier is balanced by the dagger he pushes into the left flank of his seemingly invincible enemy. As a consequence, at the dawn of August 10, I reread Vasari's comments on Leonardo's Fight for the Standard (Vasari, 1568). 


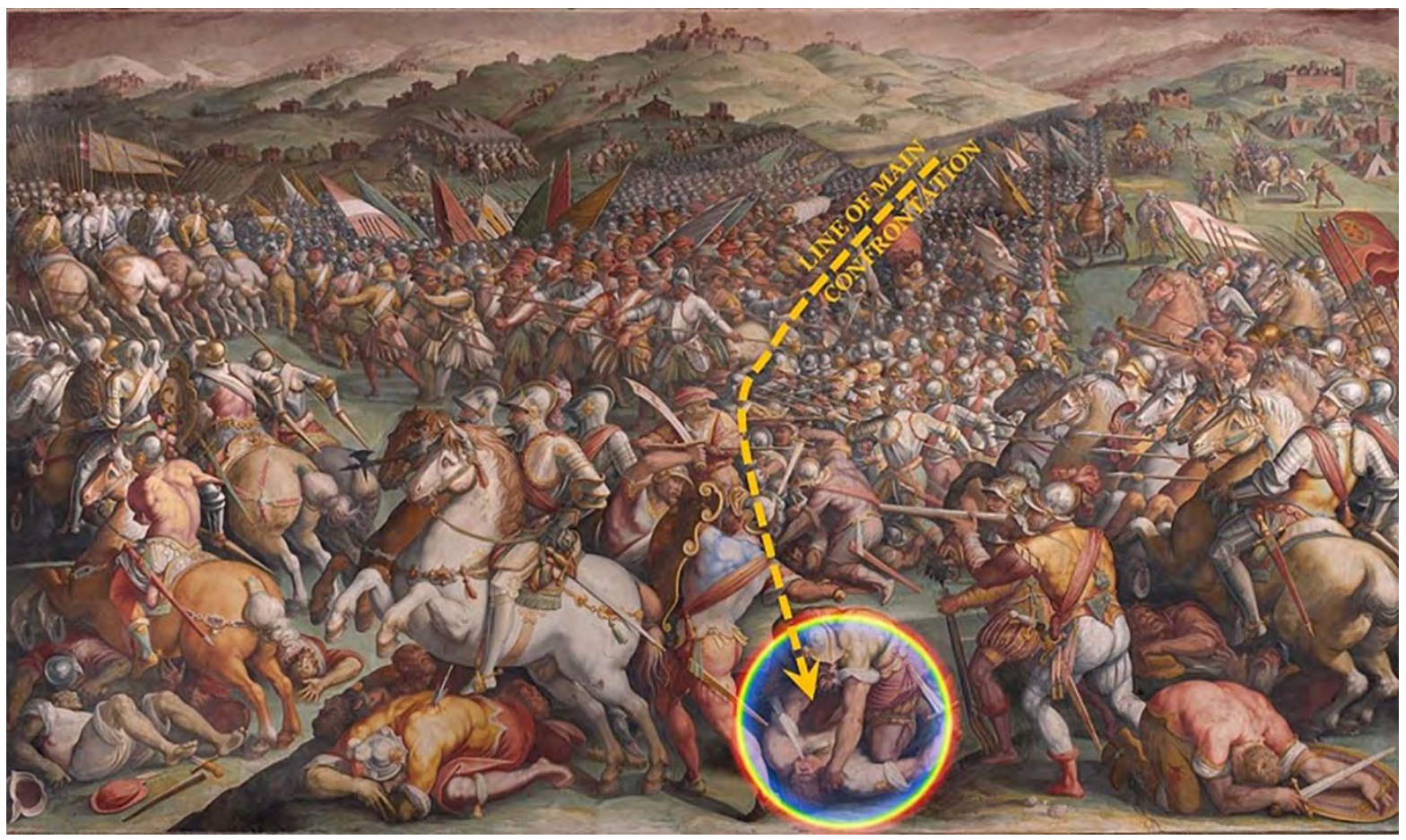

Figure 2. The ongoing fight between two soldiers in the Battle of Marciano

\subsection{The Rider with a Big Red Hat}

Vasari (1568) wrote about an impressive fight between two soldiers under the intertwined legs of horses mounted by inimical warriors in Leonardo's Fight for the Standard. He also wrote about the fierce attitude of a rider with a "berrettone rosso" ("big red hat") (Figure 3).

In Vasari's own words:

“. . . . mentre che un soldato vecchio con un berretton rosso gridando tiene una mano nell'asta, e con l'altra inalberato una storta, mena con stizza un colpo per tagliare tutte e due le mani a coloro, che con forza digrignando $i$ denti, tentano con fierissima attitudine di difendere la loro bandiera; oltra che in terra fra le gambe de' cava gli $v$ 'è due figure in iscorto, che combattendo insieme, mentre uno in terra ha sopra uno soldato, che alzato il braccio quanto può, con quella forza maggiore gli mette alla gola il pugnale, per finirgli la vita, e quello altro con le gambe e con le braccia sbattuto, fa ciò che egli può per non voler la morte".

(“. . while an old soldier with a big red hat shouts loud in seizing the pole of the flag, raising a curved sword with the other hand, and places a furious hit to cut both hands of those who, gnashing their teeth, try with all their strength to defend their standard; besides, on the ground between the legs of the horses, one can see two figures that fight each other, while the one on the ground has above him a soldier, who after rising his arm as much as he can, with that increased force places a knife at the throat of his enemy, to finish off his life, and the other with his legs and arms thrown out, does what he can to avoid death.")

After reading Vasari's detailed comment, I turned again my attention to the fact that Leonardo's Fight for the Standard contained a scene that was almost identical to the fight between two soldiers painted by Vasari in his Battle of Marciano. As with the supine soldier on the ground of Vasari's Battle of Marciano, on the ground of Leonardo's Fight for the Standard, a supine soldier (right lower portion of Figure 3), shouts loudly in an attempt to stop the impending death conveyed by the knife held by right arm of an invincible enemy.

Figure 3 shows the alignment of the larynges of the two supine and screaming soldiers under the same vertical. Because the mathematics of one vertical line cannot prove that Leonardo's mural is located in all probability under Vasari's painting, I went back to the few coincidences I showed in my June article about the crossing of two straight lines - a metaphor for the artistic facet of the human mind. 


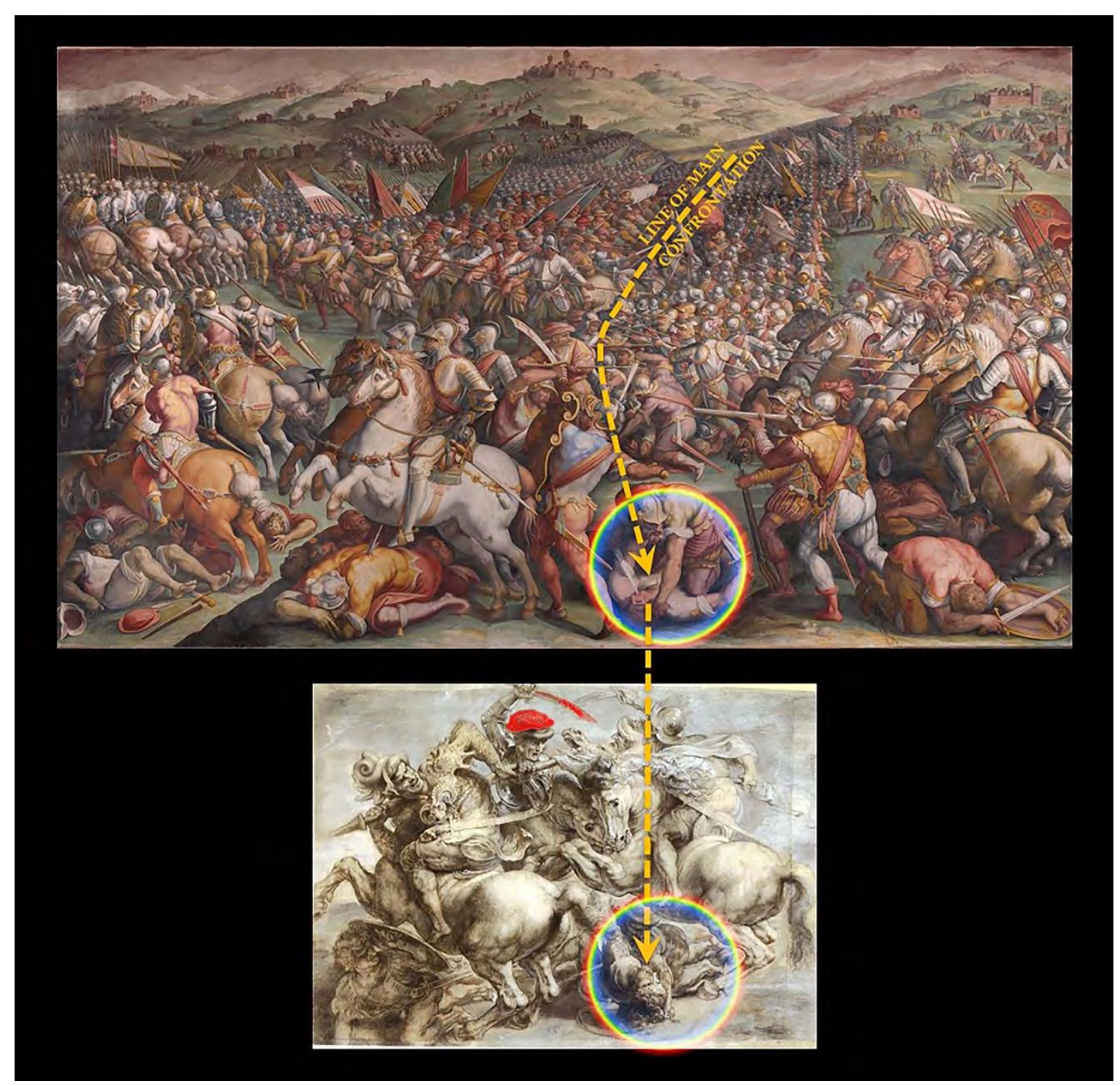

Figure 3. The ongoing fight between two soldiers in the Battle of Marciano and in the Fight for the Standard 4.6 The Battle with Infinity in Comparing Vasari's Battle of Marciano to Leonardo 's Fight for the Standard

I presume that both Leonardo and Vasari knew that the crossing of two lines, the emptiness of a cave, and the cavity of an open mouth point to the embrace of transcendental nothingness and transcendental infinity in the third eye or in the third point of a true artist.

Examples of a quantum crossing include the symbol of the logos heuristic $(\Lambda)$, a bent knee, a curved elbow, a curved foot, the origin of the leg of a horse, the shoe of a horse, the tip of a sword, the opening between the thumb and the index in a human hand, and so on. I only had to connect under the same vertical line a crossing in the Fight for the Standard with a similar crossing in Vasari's Battle of Marciano; for example, the shoe of the left foreleg of a horse drawn by Vasari with the shoe of the left foreleg of a horse drawn by Leonardo. Furthermore, because Giorgio Vasari admired Pythagoras, I imagined that he would leave behind at least ten coincidences, a hint of one sacred Pythagorean "Tetractys."

As Figure 4 demonstrates, I found three Tetractys.

The mathematics of three Tetractys can be associated with the factorial of 30,30 !, or $2.65 \times 10^{32}$. A number that high might lead a few researchers to believe that there is a high probability that the horizontal placement of Leonardo's Fight for the Standard is located in the position shown in Figure 4. 
I prefer to consider, however, that the difference between infinity and 30! would always result in the higher probability that Leonardo's horses would not be found under Vasari's Battle of Marciano. My preference led me to hypothesize that Vasari's way of firming up the horizontal placement of Leonardo's horses is based on a geometrical key.

After all, the importance of probability as a mathematical theory would have to wait 100 years for the genius of Pierre de Fermat and Blaise Pascal; and 200 years for its use in playing with the beliefs of others by Giacomo Casanova, the organizer of the first State Lottery in Paris. And yet, one cannot forget the friendship between Leonardo da Vinci and Girolamo Cardano, the first mind who wrote about how to use the mathematics of probability.

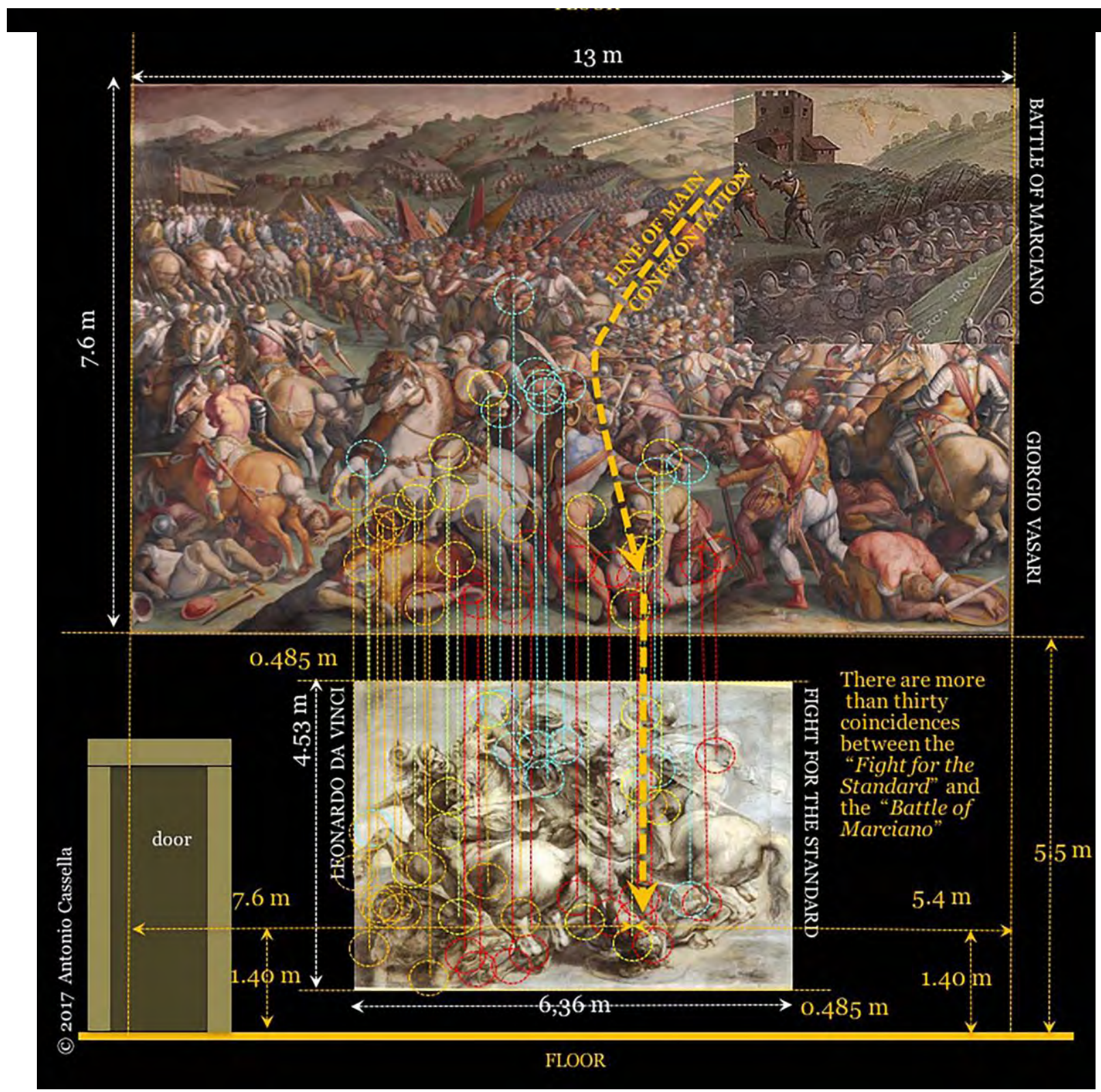

Figure 4. A view of 30 coincidences between the Battle of Marciano and the Fight for the Standard

On August 10, 2017, at twilight I examined the angry Niccoló Piccinino and his "big red hat" in Figure 3. At that point, I noticed a soldier with a similar red hat in Vasari's Battle of Marciano. Even now it seems to me that the position of that soldier is too central not to have a special meaning.

Under a new vision, I traced the two diagonals of the rectangle that hosts the Battle of Marciano (Figure 5). In so doing, I realized that that lone soldier with a red hat, in the fashion shown by Piccinino in Leonardo's Fight for the Standard, lies at the center of Vasari's painting. 
Moreover, I found that a vertical line traced down from the very center of Vasari's painting passed through the very center of Leonardo's horses.

I realized then that Vasari had aligned the center of his Battle of Marciano precisely with the center of Leonardo's Fight for the Standard. As Figure 5 shows, the two steps hinted at by Giorgio Vasari-the alignment of two screaming soldiers and the old man with a big red hat-lead to fixing the horizontal placement of Leonardo's Fight for the Standard with a zero error.

In Figure 5, I place the center of the Fight for the Standard at the center of the distance (5.5 meters) between the lower edge of the Battle of Marciano and the floor. The difference between 5.5 meters and the height of Leonardo's Fight for the Standard $(4.53 \mathrm{~m})$ gives a value of 97 centimeters, which can be distributed below and above that central piece, in line with a length of $0.485 \mathrm{~m}$. However, that planning implies the destruction of $50 \%$ of the lower frame of the Battle of Marciano.

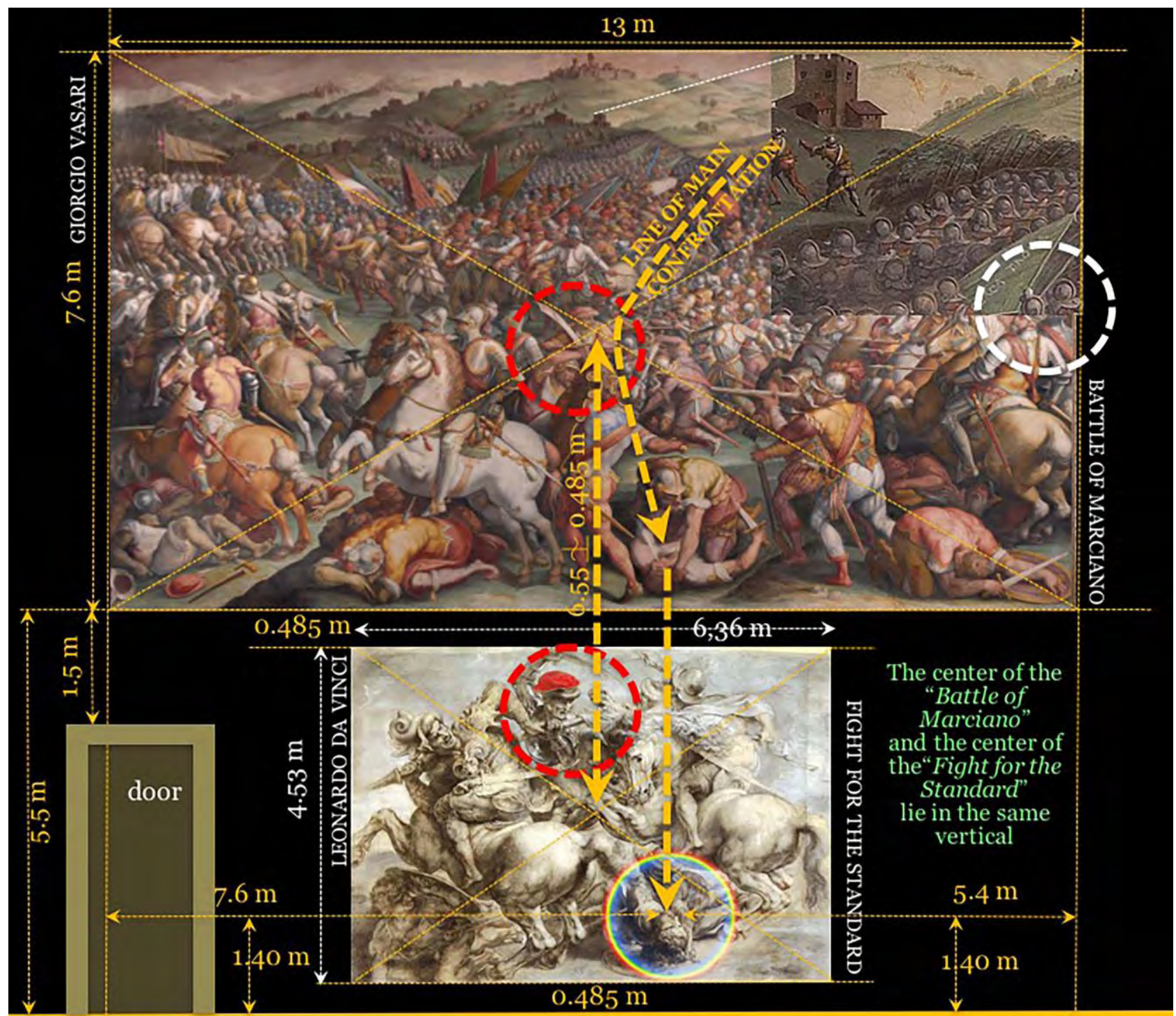

(c) 2017 Antonio Cassella

FLOOR

Figure 5. The Man with the "big red hat":

Vasari's hidden lead to fixing the horizontal placement of the Fight for the Standard

Once again, Vasari had no need to impose an "inelegant" measure that would ruin the aesthetic of the Hall of the Five Hundred. Likewise, the realization that the difference of 97 centimeters corresponds to my virtual appreciation of the 
height of the frame of the Battle of Marciano led me to lining the bottom of Leonardo's masterpiece with the surface of the floor of the Hall of the Five Hundred.

Consequently, in Figure 6, I place the open mouth of the prostrate screaming soldier in the Fight for the Standard at a distance of 0.915 meters from the floor of the Hall of the Five Hundred.

Drilling a hole at a distance of three feet from the floor, on the vertical line the comes down from the tip of the dagger in the mouth of the supine soldier in the Battle of Marciano will uncover the larynx of the prone soldier in the Battle of Anghiari and strengthen Vasari's artistic, literary, architectural, and humanistic purpose for hiding the Fight for the Standard: a posterity animated by the social aims pursued by our third attention.

One cannot discard the possibility that other parts of the Battle of Anghiari and the initial steps undertaken by Michelangelo about the Battle of Cascina will surface as an added bonus.

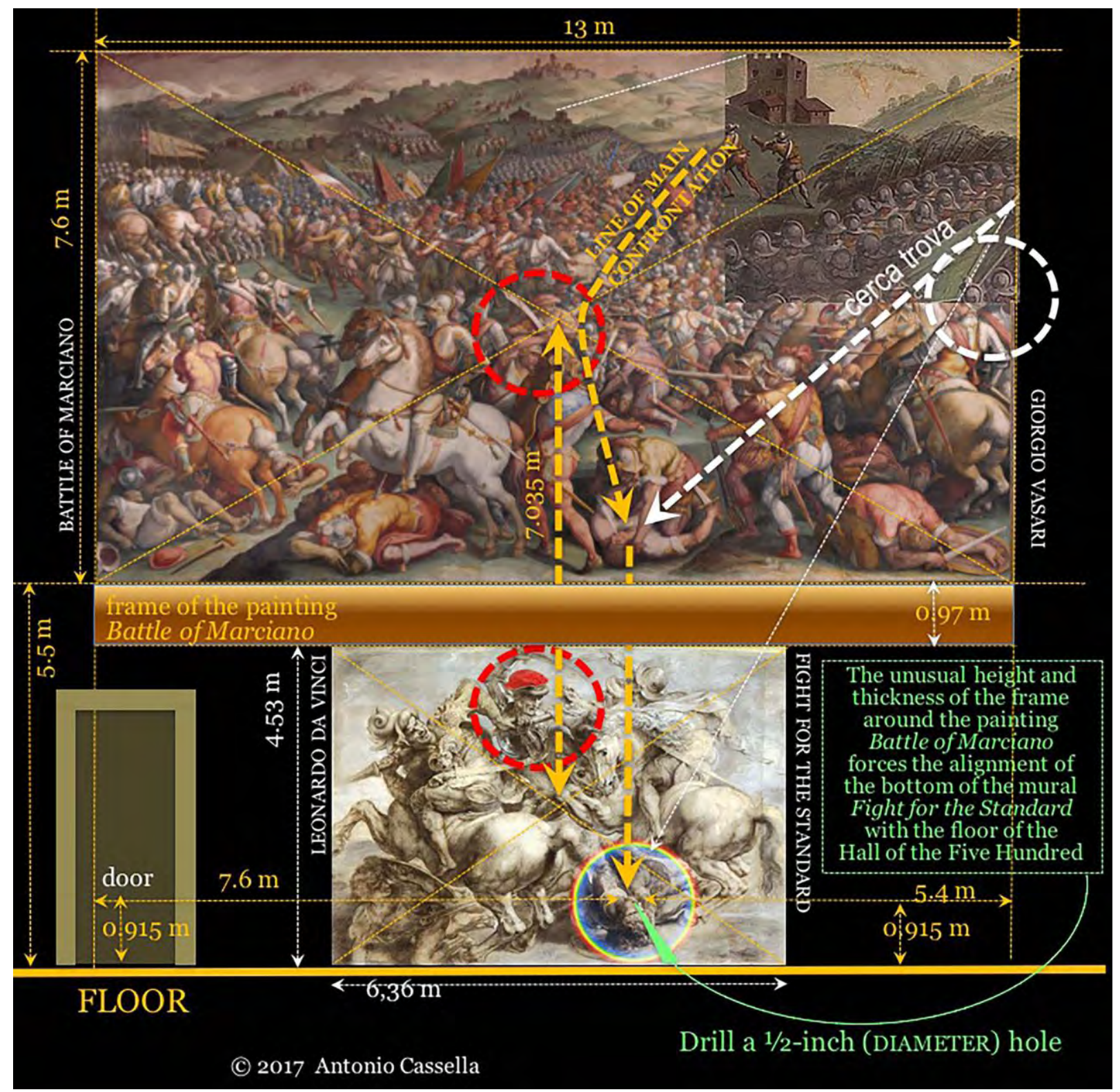

Figure 6. The height (97 centimeters) of the frame of the Battle of Marciano represents Vasari's second clue to fixing the vertical placement of the Fight for the Standard

Figure 7 offers a re-adjusted view of the East Wall of the Hall of the Five Hundred in comparison to the view that I offered in my June article (Cassella, 2017c).

As I did in my June article, at the bottom left of Figure 7, I place the portraits of four champions of the unilateral use of the second attention. In his work Il Principe (The Prince), Niccolò Machiavelli (1814) praised directly the diabolical 
cunning of Cesare Borgia. Il Principe implies indirectly that empowered liars in the world rely on the infinite speed introduced by quantum coherence, which autistics cannot grasp. For example, the selfishness, greed, courage, and fear of Cesare Borgia's first attention relied on the infinite speed of his second attention when he deceived his own "condottieri." Although Machiavelli was impressed by Cesare Borgia, the wicked betrayal implanted by the legendary Prince was neither humane nor humanistic.

At the bottom right of Figure 7, I place four champions of the humanistic use of the second attention, within the infinite speed of quantum decoherence, which schizophrenics seize by chance (e.g., Vincent van Gogh) or by using medication (e.g., the mathematician John Nash). The four characters at the bottom right of Figure 7 can be truly seen as heralds of the third attention, which all nonautistics children can reach if they are not brainwashed first by the malevolent individuals who rob them of their ability to assert their creative voice.

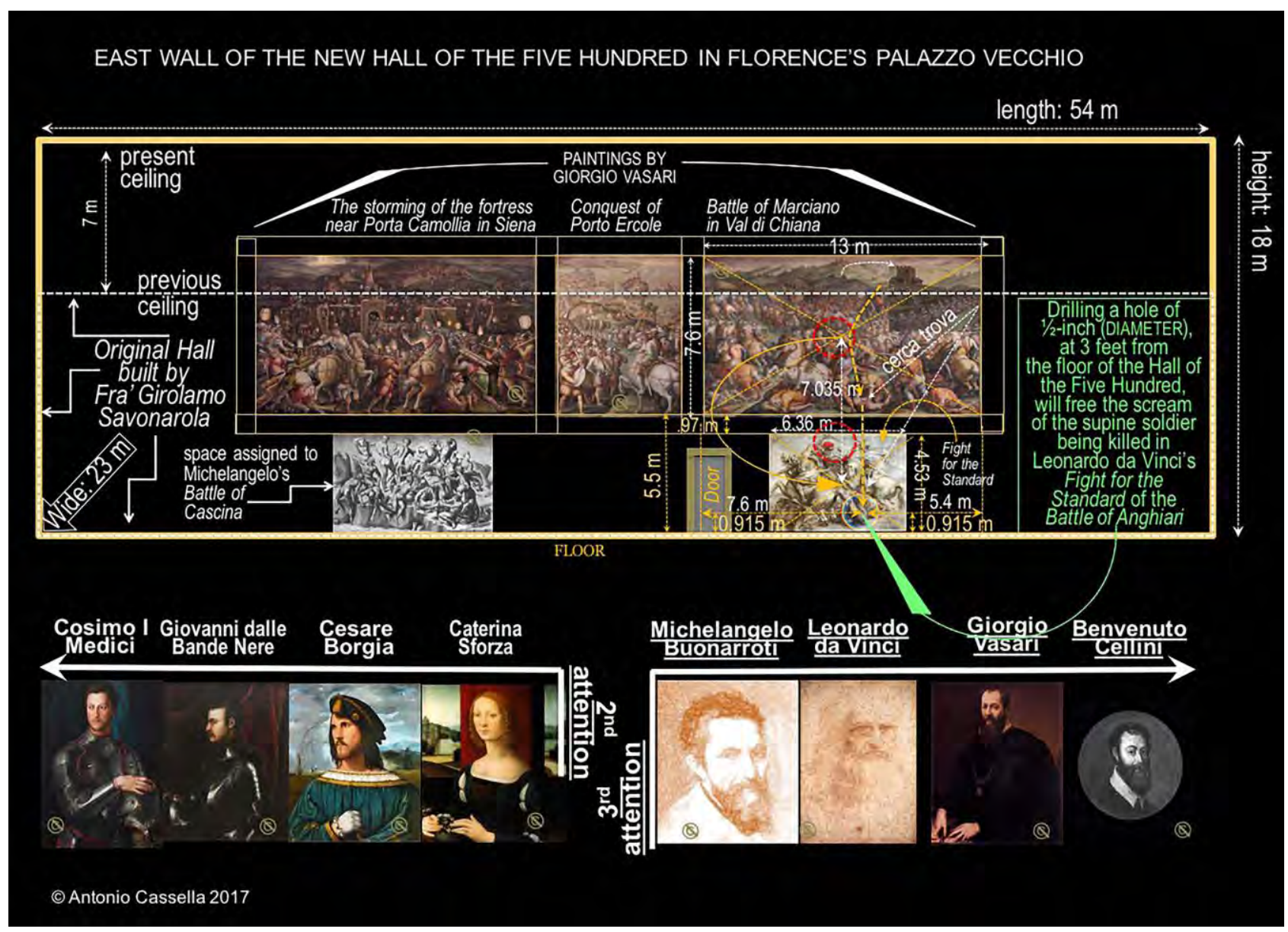

Figure 7. A renewed view of the horizontal and vertical placement of Leonardo's Fight for the Standard in the East Wall of the Hall of the Five Hundred at Florence's Palazzo Vecchio

Just as Florence did against Pisa in the Battle of Anghiari, and against Siena in the Battle of Marciano, humans must empower their first attention and the possibility of entering bloody confrontations. Recall that there are two sides to any confrontation. Invalidating the existence of one side by immediately favoring the opposite side ousts an understanding of the roots of human intellect. Smart leaders do not make that mistake.

Our first attention compels us at all times to abandon both the talent of the second attention and the social inclination of the third attention. Because the refusal to acknowledge the roots of humane intelligence stands to destroy our children, our country, and the world, we should praise the second attention of the mind that does not take sides immediately when facing conflict laden with violent intentions from contrary factions.

Although it points at the classical principles of the first attention (Locality and Impenetrability), Leonardo's unresolved Fight for the Standard implies the quantum principles of the second attention (Ubiquity and Coincidence).

Indeed, the hunter that takes sides with opposite sides simultaneously will leave the principles of Locality and Impenetrability behind - as Leonardo did; will embrace the infinity attached to Ubiquity and Coincidence in the second 
attention, as a warrior would; and, eventually, will unite the principles of the classical computing rooted in the Tonal-Thummim-Hovalim with the principles of quantum computing rooted in the Nagual-Urim-No'am.

Buddhists call "Tathāgatha" ("thus gone and thus come") the warrior who goes as a devil with the second attention and quantum coherence and returns as a Saint with the third attention and quantum decoherence.

Mesoamerican legends carry the belief that the third attention will invite Quetzalcoatl to return from Venus, after leaving behind the diabolical inclination of his second attention. That feat leads us to believing that, in the wake of Quetzalcoatl, some man- or woman-of-knowledge will teach our quantum second attention how to rise justly above the classical confrontations that feed the hatred for our enemies, our greed, and the love for the self.

\section{Concluding Remarks}

Without the confrontational dichotomy of good and bad, right and wrong, and ugly and beautiful, reality vanishes. Conflict and hunting make the "salt of life," but the lack of the second attention in factions that cannot share the same space at the same time leads to the shared sterility that precedes mental blindness and pervasive death. For example, the inability to rise above a confrontation caused the relentless enmity between communism and fascism 80 years ago; and the ability to nullify confrontations at will fosters the present amity between fascism and communism in a few undemocratic societies.

In contrast with societies led by the second attention of an emperor, true democratic societies value the third attention in allowing the rise of conflict and in lawfully punishing violent trespassers.

The fact that Florentines admired in early 1505 Leonardo's unresolved Fight for the Standard suggests that their leaders valued implicitly the humanistic use of the second attention behind the Renaissance that animated Florence in the $16^{\text {th }}$ century. Unfortunately, the second attention can be used by astute tyrants to achieve a definite victory over competitors at the lowest cost-for example, through wicked deception and the use of proxies. The intervention of undemocratic countries in the elections of democratic countries, their subtle invasion of a weak nation, and their support of dictators sustained by armies of brainwashed acolytes imply that the second attention and the first attention in the mind of a tyrant, can strike a malevolent alliance in supporting hatred, ambition, betrayal, lying, arrogance, narcissism, corruption, mischievous over-confidence, and in the end, sheer madness. Graceless leaders will definitely fall in the basket of the false virtues admired by loyal acolytes, unable to envision and solve the problems hidden in violent confrontations .

The graceful art behind the Fight for the Standard suggests that Leonardo understood that any confrontation attached to the first attention hides an invitation to our second attention to seek an underlying problem, and an invitation to our third attention to solve that problem for the benefit of all stakeholders. Indeed, the first attention becomes the second attention and even the third attention in the person who refuses to side immediately with one of the two extremes of a conflict, confronts the problem behind violence, controls his or her anger at the unfairness of blind criticism, and solves that problem elegantly because he or she wishes the best to faultfinders imprisoned by ideology or by lack of knowledge about the alliance of classical rigidity and quantum flexibility in nature and in the humane mind.

Tyrants and arrogant leaders in love with the power to impose their own unilateral will will not overcome the disruption caused by terrorists on the loose and by the phenomenon of anthropic global warming. By contrast, I believe that uncovering Leonardo's vanished mural about the Fight for the Standard in the Battle of Anghiari will help us:

1. value the spacetime of the first attention that coatl-minded, high-functioning autistics maintain without medication, and quetzal-minded schizophrenics cannot maintain without medication;

2. go with the devilish Quetzalcoatl into the hyperspace (Caramazza, 1994) of the second attention, which abandons both autistics and unmedicated schizophrenics; and

3. return with the secret of the third attention and the awakened Quetzalcoatl to a world renewed for all.

In other words, if a humanistic approach frees from prison Leonardo's artistic representation of the Fight for the Standard, a global Renaissance will: a) motivate the world into undoing the brainwashing of terrorists, racists, and fundamentalists; b) arrest the strategy of a few narcissistic tyrants who believe that they are smarter than Machiavelli's Prince; c) allow natural global cooling to decrease the temperature of the lower atmosphere by 2 degrees Celsius; and d) free our descendants to explore in the next 7000 years the Earth-like planet that adorns Alpha Centauri.

In summary, the race of our civilization from spiraling toward premature death can be stopped by drilling one 1/2-inch (DIAMETER) hole on the east wall of the Hall of the Five Hundred, at a height of 0.915 meters (about three feet) from the floor, on the vertical line that comes down from the tip of the dagger placed in the mouth of the prone soldier on the ground of the Battle of Marciano.

In this article, I found and embraced the hidden elegance of Giorgio Vasari' words and measures to help us uncover precisely Leonardo's Fight for the Standard. I presume that he concealed the location of the Fight for the Standard for a 
posterity inclined to humane and humanistic approaches. I cannot know how Vasari protected Leonardo's mural; neither can I embrace the arrogance of believing that I can convince other people that I am right about the exact location of the Fight for the Standard. I believe that the act of imposing on others our beliefs or of deceiving them in order to steal from them what we want does not fit the beauty in which we all believe. By contrast, when we take from others what they want to give us, we reject the rigid will of winning over them and embrace instead the flexible hope of winning them over.

\section{Acknowledgements}

I am deeply indebted to Professor Emeritus Martin Kemp of the University of Oxford for guiding this humanistic search.

\section{Brief Biography of Antonio Cassella}

The web page of the author can be reached by placing the words "Antonio Cassella" in the space set aside for authors at Amazon Kindle. The author can be contacted at researchautism.1@gmail.com.

EdD: Teaching and Research (UNESR: Universidad Nacional Experimental Simón Rodríguez, Caracas);

MA: Psychology (Harvard University, Cambridge [MA]);

BSc: Petroleum Engineering (LUZ: La Universidad del Zulia, Maracaibo).

Antonio Cassella was born in Ethiopia in 1940. He enjoyed his high-school education in Italy and in Venezuela. He obtained a BSc in Petroleum Engineering from LUZ in Maracaibo in 1965. In the next 17 years Antonio developed new oil fields in the tidal bay of Maracaibo with Creole Petroleum Corporation (a subsidiary of Esso/ExxonMobil), Lagoven SA, and PDVSA (Petróleos de Venezuela). The need to remove hydrogen sulfide from associated gas led him to working in 1976 for EPRCO (Exxon Production Research) in Houston.

Between 1983 and 1993 Cassella worked in Strategic Planning of PDVSA in Caracas. As a visiting scientist at MIT-CEEPR (Massachusetts Institute of Technology-Center for Energy and Environmental Policy Research, Cambridge [MA]), between 1994 and 1997 his diurnal research led to establishing two scenarios of the global growth of population, energy, and the economy until 2060.

In June 1997, his nocturnal research on the psychological roots of autism and creative intelligence brought him a Master's degree in Psychology and the Award for Outstanding Thesis in the Area of Natural and Human Sciences from Harvard University.

In 2001 Antonio Cassella received in Caracas a Doctoral degree in Research and Teaching in Sciences of Education from UNESR. His writings in Italian, Spanish, and English (only at Amazon Kindle) show that combining the local certainty sought by our autistic self with the nonlocal doubt sought by our artistic self may help modern society to defuse fanaticism and global warming, while regenerating the Commons of the Earth-among them, the atmosphere and the cycle of water.

Since 2014, Antonio directs the research effort of Research Autism. Research Autism has published a series of four documentary-films on the logos heuristic in English, Spanish, and Italian. The first link of the English series is https://youtu.be/htt6xh2i5B8; the first link of the Spanish series is https://youtu.be/wNh0CgZtJMU; and the first link of the Italian series is https://youtu.be/hbcW4Z12Vu8.

\section{References}

Albertini, F. (1510). Memoriale di molte statue et picture sono nella inclyta cipta di Florentia, in De Waldemar H. Boer (Ed.) Memorial of many statues and paintings in the famous city of Florence. Exeter (United Kingdom): Centro Di.

Anonimo, G. (16 ${ }^{\mathrm{mo}}$ secolo; 1893; 26 maggio 2014, fol. 121). Il Codice dell'Anonimo Gaddiano nella Biblioteca nazionale di Firenze. http://vinciana.blogspot.com/2014/05/1893-c-de-fabriczy-il-codice.html

Caramazza, A. (1994). Parallels and divergences in the acquisition and dissolution of language. Philosophical Transactions of the Royal Society of London, Series B. 346, 121-127. https://doi.org/10.1098/rstb.1994.0136

Cassella, A. (1997). Self-other differentiation and self-other integration from the perspectives of language development and autism. (Unpublished master's thesis). Harvard University, Cambridge, USA.

Cassella, A. (2000). Fundamentos cognitivos y semióticos de la creatividad: Aportes del autismo. (Tesis doctoral con mención publicación). Universidad Nacional Experimental Simón Rodríguez(UNESR), Caracas, Venezuela.

Cassella, A. (2002a). El desarrollo de la inteligencia social: Aportes del autismo. Maracaibo, Venezuela: Ediluz.

Cassella, A. (2002b-2016). The Flameless Fire: From autism to creative intelligence. Quincy (MA): Logosresearch. (Re-edited through Amazon Kindle in a digital format by Research Autism in 2017; 
https://www.amazon.com/s?ie=UTF8\&page=1\&rh=n\%3A133140011\%2Cp_27\%3AAntonio\%20Cassella).

Cassella, A. (2008). Readjusting what we know with what we imagine. In R. Allen (Ed.) Human ecology economics: A frameworkfor global sustainability (pp. 230-257). London: Routledge.

Cassella, A. (2011, June). Autism and the interplay of deterministic and quantum information processing in the act of creation. Neuroquantology, 9(02), 271-287.

Cassella, A. (2013). Neurobiological correlates of classical and quantum neural computing from the perspective of autism. In V. B. Patel, V. B. Preedy, \& C. R. Martin (Eds.), The comprehensive guide to autism (pp. 865-890). London: Springer. https://doi.org/10.14704/nq.2013.11.2.623

Cassella, A. (2016). The psychological roots of creativity in messages left by Leonardo da Vinci, Giorgio Vasari, and a Neanderthal troglodyte. Journal of Arts and Humanities, 5(8), 12-28.

Cassella, A. (2017a). Thus returned Quetzalcoatl: An interview with Antonio Cassella concerning the Dance of locality and nonlocality. Melbourne (FL): Research Autism. (Series of 3 volumes in English, Spanish, and Italian). https://www.amazon.com/s?ie=UTF8\&page=1\&rh=n\%3A133140011\%2Cp_27\%3AAntonio\%20Cassella.

Cassella, A. (2017b). An unlawful look at an extraordinary theory-of-everything: Answers to fifteen questions concerning the dance of locality with nonlocality. Melbourne (Florida): Research Autism. (Edited in English, Spanish, and Italian).

Cassella, A. (June 2017c). Re-directing climate change and terrorism by allying classical with quantum neural computing. International Journal of Social Science Studies, 5(6), 94-115. https://doi.org/10.11114/ijsss.v5i6.2439

Cassella, A. (2017d, documentary-film). An unlawful look at an extraordinary theory-of-everything: Answers to 15 questions concerning the dance of locality with nonlocality. Melbourne (FL): Research Autism(YouTube).

Cassella, A. (2017e, documental). Una ojeada ilícita a una extraordinaria teoría-del-todo: Respuestas a quince preguntas sobre una extraordinaria teoria-del-todo. Melbourne (FL): Research Autism(YouTube).

Cassella, A (2017f, documentario). Un'occhiata illecita a una straordinaria teoria-del-tutto; Risposte a quindici domande sulla danza della località con la non località. Melbourne (FL): Research Autism(Youtube)

Castaneda, C. (1968). The teachings of Don Juan: A Yaqui way of knowledge. NewYork, Simon and Schuster.

Castaneda, C. (1974). Tales of power. New York: Simon and Schuster.

Castaneda, C. (1981). The Eagle's gift. New York: Simon and Schuster.

Godart, L. (2012). La Tavola Doria: Sulle tracce di Leonardo e della "Battle of Anghiari” attraverso uno straordinario ritrovamento. Milano: Mondadori.

Hatfield, R. (2007). Finding Leonardo: The case for recovering the Battle of Anghiari. Prato (Italy): The Florentine Press.

Kemp, M. (2006). Leonardo da Vinci. The marvelous works of nature and man. Oxford: Oxford University Press.

Lomazzo, G. P. (1785). Idea del tempio della pittura. Bologna: Accademia delle Scienze.

Machiavelli, N. (1814). Il Principe (a cura di Luigi Firpo). Torino: Einaudi

Rehhof, P., Akkermans, E., Leonardsen, E, \& Thuesen, I. (1990). Plasters: Gypsum or Calcite? A preliminary case study of Syrian plasters. Paleorient, 16(2), 79-87. https://doi.org/10.3406/paleo.1990.4534

Tiraboschi, G. (1823). Storia della letteratura italiana del cav. Abate Girolamo Tiraboschi, Tomo 7, Parte 4: Dall'anno 1500 fino all'anno 1600. Milano: Società tipografica de' classici italiani.

Vasari, G. (1568). Le vite de' più eccellenti architetti, pittori, et scultori italiani, da Cimabue insino a' tempi nostri. Firenze (1568): Giunti.

\section{Copyrights}

Copyright for this article is retained by the author(s), with first publication rights granted to the journal.

This is an open-access article distributed under the terms and conditions of the Creative Commons Attribution license which permits unrestricted use, distribution, and reproduction in any medium, provided the original work is properly cited. 